\title{
PERFORMANCE EVALUATION OF MAGNUS SCREW PRESS (MODEL MS-100) FOR PALM KERNEL OIL EXTRACTION
}

\author{
S. L. Ezeoha ${ }^{1}{ }^{*}$, C. O. Akubuo ${ }^{2}$, E. U. Odigboh ${ }^{3}$ and M. Arallo ${ }^{4}$ \\ 1,2,3 Dept. of Agricultural and Bioresources EngineERING, Univ. of NigERIA, NSUKKA. ENUGU STATE. NigERIA \\ 4 Magnus Materials Fabrication, No. 4, Mbuke StreEt, NSUKKa, EnUgu StATE. NiGERIA. \\ E-mail addresses:1'sunday.ezeoha@unn.edu.ng, ${ }^{2}$ clement.akubuo@unn.edu.ng,3 odigboh@gmail.com, \\ 4 magnustechnical@gmail.com
}

\begin{abstract}
The screw (expeller) press is extensively used for commercial extraction of palm kernel oil (PKO) from oil-palm kernels. In this work, Magnus (Nig.)screw press (Model MS-100,) locally fabricated at Nsukka, Nigeria was evaluated for throughput capacity, feed rate, press cake oil content, oil expelling efficiency (OEE), percentage un-pressed grits output, percentage sludge output, and specific energy consumption. One-factor-at-a-time (OFAT), completely randomized designed (CRD) experimental approach with 4 factor levels and 2 replications was used to determine the effect of kernel moisture contents (KMC), kernel heating temperatures (KHTs), and kernel heating durations (KHDs) on the (OEE) of the screw press. Analysis of variance (ANOVA) technique was used to analyze the results. In its best operating settings, the $M S-100$ screw press has a throughput capacity of $91.7 \mathrm{~kg}$-products/h at an average feed rate of $101.7 \mathrm{~kg}-\mathrm{kernels} / \mathrm{h}$, press cake oil content of $13.6 \%(\mathrm{w} / \mathrm{w})$; percentage actual oil yield of $33.6 \%(\mathrm{w} / \mathrm{w})$; percentage cake output of $38 \%(\mathrm{w} / \mathrm{w})$; percentage un-pressed kernel grits output of $14.2 \%(\mathrm{w} / \mathrm{w})$; percentage sludge output of $3.6 \%(\mathrm{w} / \mathrm{w})$; OEE of $73 \%$; and specific energy consumption of $0.44 \mathrm{kWh} / \mathrm{kg}$-kernels. The screw press is adjudged suitable for palm kernel oil extraction based on its OEE. The ANOVA of the results show that the best kernel factors for highest OEE include KMC of 5\% w.b.; KHT of $50-130^{\circ}$ C; and KHDs of $5-10$ min. The $14.2 \%$ un-pressed kernel grits output, however, is a problem of Magnus Screw Press that needed to be reduced or eliminated through design modifications.
\end{abstract}

Keywords: Palm kernel oil, screw press, oil extraction, Magnus screw press

\section{INTRODUCTION}

Processing of oil palm fruits has been practiced in Africa for thousands of years. The oil-palm fruit when processed yields palm oil, mesocarp fibre, and palm nut; and the nut when cracked yields palm kernel and shell. Palm nut shell is an aggregate replacement material in concrete production [1]. It is also an economically and environmentally sustainable raw material for renewable energy $[2,3]$. Palm nut shell ash serves as an admixture (accelerator) in concrete production [4].The importance of palm kernel derives from the economic importance of the bye-products, namely, the PKO, and the palm kernel cake (PKC). PKO as food is a source of concentrated energy [5]. The oil could be used as a lubricant and an emulsifier [6]. It is an ingredient in paint making as a drying base, and in the manufacture of candles and soaps $[6,7]$.

The screw pressing method is extensively used in Nigeria for commercial extraction of PKO from palm kernels. Olawepo and Balogun [8] conducted a performance evaluation of a PKO extraction screw press. The performance parameters investigated were practical oil yield and press efficiency. Olayanju et al. [9] identified machine capacity or throughput and power requirements amongst the machine parameters of vegetable oil expellers. A manually-operated screw piston-press was designed, constructed and tested for village level groundnut oil expression [10]. The press was tested for efficiency, throughput capacity, and durability. Olayanju [11] evaluated the performance of a beniseed oil expeller based on efficiency expressed in terms of oil recovery. Other indices of screw press performance may include: press cake oil content, feeding characteristics of the press, press susceptibility to damage from tramp metals, vibration, rigidity, abrasive wear rate, sufficiency of hopper outlet, etc. [12]. Ojomo et al. [13] evaluated a locally fabricated oil screw press using such indices as feed rate, capacity, percentage oil recovery, machine efficiency, and oil yield. The most important performance indices for a screw press, 
however, include feed rate, throughput capacity, cake oil content, and oil expelling efficiency. The Magnus screw press (Model MS-100) is locally fabricated at Nsukka, Nigeria [14]. This press is in use by several small to medium scale vegetable oil businesses to extract crude palm kernel oil (CPKO) from oil-palm kernels. There are, however, no available records or published materials showing that the screw press has ever been evaluated or characterized.

The objective of this study, therefore, was to evaluate the performance of Magnus (Nig.) MS-100 screw press with respect to its through put capacity, feed rate, press cake oil content, percentage actual oil yield, percentage cake output, percentage un-pressed grits output, percentage sludge output, oil expelling efficiency, and specific energy consumption so as to pronounce on the suitability or otherwise of the screw press for palm kernel oil extraction and the need for any design improvements.

\section{MATERIALS AND METHODS}

\subsection{Description of Magnus (Nig.) Screw Press:}

The screw press is used to crush and extract PKO from palm kernels in either a continuous or batch mode operation. It consists of a hopper, an extraction unit, oil collection and discharge unit, cake collection and discharge unit, a prime mover, and the frame. The hopper is conical in shape and made of $5 \mathrm{~mm}$ gauge galvanized iron sheet. The extraction unit is essentially a helical thread welded on a straight shaft which revolves within a stationary perforated cylindrical barrel. The oil collection and discharge unit is a sheet metal tray that is tapered to a spout. The cake collection and discharge unit is also a metal tray inclined downwards for easy discharge of cakes. The prime mover is a $45 \mathrm{~kW}, 3$-phase electric motor of $1470 \mathrm{rpm}$ speed with vee-belts and pulley arrangement connected to a speed-reduction gearbox which in turn is connected to a universal joint coupled to the screw shaft. The screw is a straight-type, with decreasing worm-pitch. The choke arrangement is designed to achieve effective extraction of oil. The press is driven at an extraction speed of $56 \mathrm{rpm}$. The metal frame supports the screw press and the prime mover; all held together with bolts and nuts to allow for easy dismantling for transportation. Figure 1 is the photograph of the screw press. Other technical specifications are shown in Table 1. In operation, kernels are fed through the hopper; the screw conveys, crushes, grinds, and presses the grits against the barrel thereby squeezing out the PKO. The oil is collected and discharged by the oil collection unit; while the residual cake is collected and discharged by the cake (chaff) collection unit.
Table 1: Some technical specifications of Magnus (Nig.) Screw Press (MS-100)

\begin{tabular}{ll}
\hline Item & Dimensions \\
\hline Capacity & $101.7 \mathrm{~kg} / \mathrm{h}$ \\
Screw shaft length & $820 \mathrm{~mm}$ \\
Minimum screw shaft diameter & $46 \mathrm{~mm}$ \\
Hopper outlet diameter & $74 \mathrm{~mm}$ \\
Minimum screw pitch & $70 \mathrm{~mm}$ \\
Maximum screw pitch & $90 \mathrm{~mm}$ \\
Screw height & $15 \mathrm{~mm}$ \\
Screw thickness & $10 \mathrm{~mm}$ \\
Screwed shaft length & $250 \mathrm{~mm}$ \\
Press' cage diameter & $83 \mathrm{~mm}$ \\
Press' cage length & $355 \mathrm{~mm}$ \\
Average helix angle & $17 \mathrm{degrees}$ \\
Screw choke gap & $1.85 \mathrm{~mm}$ \\
\hline
\end{tabular}

2.2 Experiments for Evaluating Press Performance Indices One-factor-at-a-time (OFAT), completely randomized designed (CRD) experimental approach with 4 factor levels and 2 replications was adopted. Four different batches (B1 - B4) of palm kernels were purchased at a local market in Nsukka and used for the performance evaluation tests. Four samples of B1 kernels (500 g each) at different moisture contents $(3,5,7$, and $10 \%$ (w.b.) were cleaned and heated at $130^{\circ} \mathrm{C}$ for $10 \mathrm{~min}$ in an oven. The above range of moisture contents were selected based on previous study [15] and on what is normal for palm kernels sold at local markets in Nsukka [16]. Each sample was processed using the press and all the outputs (oil, cake, un-pressed grits, and sludge) were separately collected and weighed. The processing time per sample was noted. Another 4 samples of B2 kernels (500 g each) at $3 \%$ moisture content $(\mathrm{wb})$ were cleaned and heated at 4 different temperatures $\left(30,50,90,130^{\circ} \mathrm{C}\right)$ for 10 minutes. The selected temperatures were based on previous study [15]. Each sample was then processed using the press; and all the outputs (oil, cake, un-pressed grits, and sludge) were separately collected and weighed. The time taken to process each $500 \mathrm{~g}$ sample was noted. Again, another 4 samples of B3 oil-palm kernels (500 g each) at $6.6 \%$ moisture content $(\mathrm{wb})$ were cleaned and heated at $80^{\circ} \mathrm{C}$ for different heating times $(5,10,15$, and $20 \mathrm{~min}$ ); the heating times were also based on previous study [15]. Each sample was processed using the screw press; and all the outputs (oil, cake, un-pressed grits, and sludge) were separately collected and weighed. The processing time per sample was also noted. Percentage actual oil yield, percentage cake output, percentage unpressed grits output, percentage sludge output, and press throughput capacity (TC) were calculated from equations (1), (2), (3), (4), and (5) respectively. The oil expelling (extraction) efficiency of the screw press was computed from equation (6). 


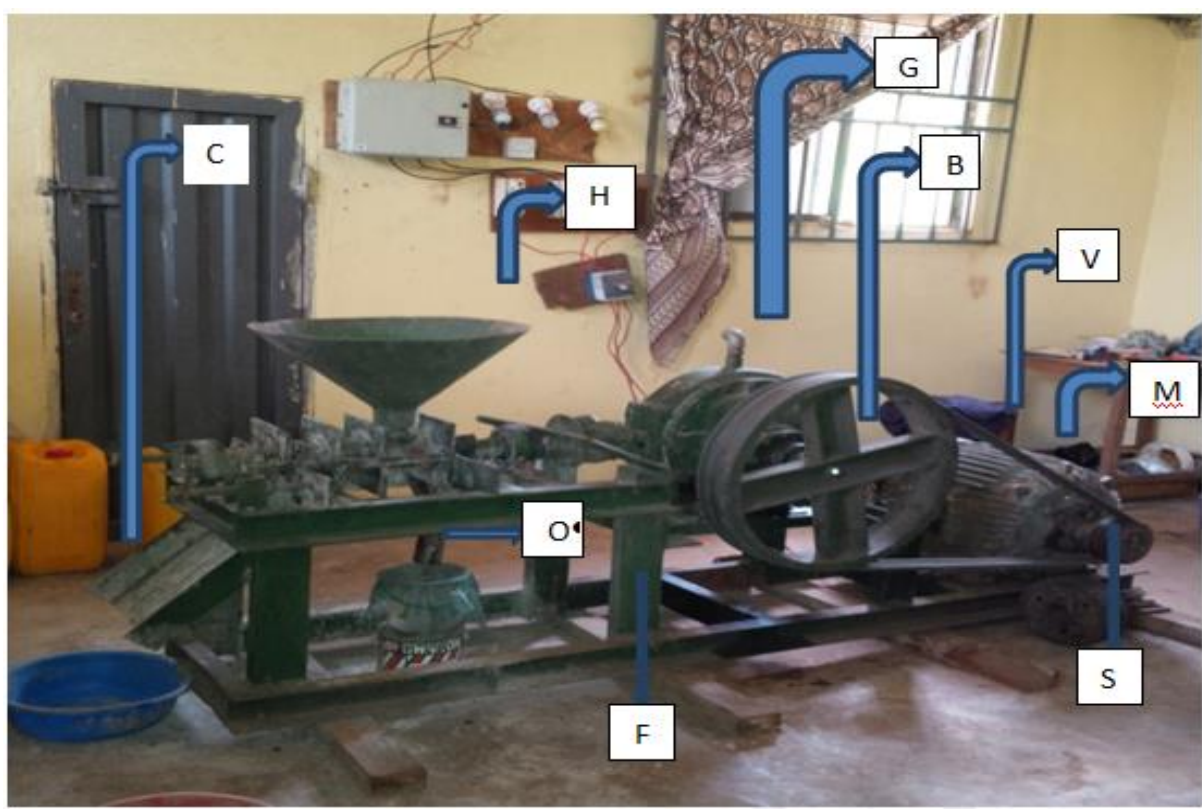

Figure 1: Photograph of $M S$-100 Screw Press ( $O=$ oil collection/discharge unit, $C=$ cake collection and discharge unit, $H=$ hopper $G=$ gearbox, $B=$ big pulley, $V=$ veebelt, $M=$ motor $S=$ small pulley, $F=$ frame)

The results of the OFAT experiments were analyzed using the analysis of variance (ANOVA) technique.

$$
\mathrm{PAOY}=\frac{A A O Y}{M K S} \times \frac{100}{1}
$$

Here, PAOY is the percentage actual oil yield (\%), AAOY is the average actual oil yield (g) and MKS is the mass of kernel sample (g)

$$
\mathrm{PCO}=\frac{A C O}{M K S} \times \frac{100}{1}
$$

In (1), PCO is the percentage cake output (\%), ACO is the average cake output (g) and MKS is the mass of kernel sample (g)

$$
\mathrm{PGO}=\frac{A G O}{M K S} \times \frac{100}{1}
$$

In (3), PGO is the percentage un-pressed grits output (\%) and AGO is the average un-pressed grits output $(\mathrm{g})$

$$
\text { PSO }=\frac{A S O}{M K S} \times \frac{100}{1}
$$

In (4), PSO is the percentage sludge output (\%) and ASO is the average sludge output after decantation (g)

$$
\mathrm{TC}=\frac{T O}{A P T}
$$

Here, TC is the output capacity of the press $(\mathrm{kg} / \mathrm{h}), \mathrm{TO}$ is total mass output from a sample (g) and APT is average processing time per sample $(\mathrm{h})$

$$
\mathrm{OEE}=\frac{A O Y}{M O Y} \times \frac{100}{1}
$$

Here, OEE is the oil expelling (extraction) efficiency of the press (\%), AOY is the actual oil yield (g) and MOY is the maximum or theoretical oil yield (g), MOY is the kernel oil content (KOC (\%)) multiplied by MKS (g)

Finally, $48 \mathrm{~kg}$ of B4 kernels were cleaned and heated at $80^{\circ} \mathrm{C}$ for 10 minutes and divided into 5 samples of 5,6 , 10,12 , and $15 \mathrm{~kg}$ each. Each sample was processed and the processing time recorded with a stop watch. The press feed rate was calculated using equation (7). A press cake sample from each kernel sample was analyzed for oil content using the solvent extraction method. The specific energy consumption for each process was calculated using equation (8).

$$
\mathrm{FR}=\frac{M K S}{S P T} \times \frac{100}{1}
$$

Here, FR is the feed rates of the screw press $(\mathrm{kg} / \mathrm{h})$, MKS is the mass of kernel sample (g) and APT is the average processing time per sample $(\mathrm{h})$

$$
\mathrm{SEC}=\frac{P R * T}{M K S}
$$

In (8), SEC is the specific energy consumption of the press $(\mathrm{kWh} / \mathrm{kg}$-kernels), PR is electric motor power rating $(\mathrm{kW})(=45 \mathrm{~kW}), \mathrm{T}$ is time taken to complete a process operation (h) and ${ }^{*}$ is the multiplied by

\section{RESULTS, ANALYSIS AND DISCUSSION}

\subsection{Results of Experiments for Evaluating Press Performance Indices}

Table 2 shows the results of batch 1 palm kernels processed at 4 different moisture contents for the assessment of actual oil yield, cake output, un-pressed grits output, sludge output, throughput capacity, and oil expelling efficiency. The average processing time per sample size of $500 \mathrm{~g}$-kernel was 17.7 seconds $(0.0049 \mathrm{~h})$. The average actual oil yield and oil expelling efficiency from this table is $164.2 \mathrm{~g} / 500 \mathrm{~g}$-kernels and $71.1 \%$ respectively. Tables 3 and 4 show the results for batch 2 and 3 with averages of 163.3 and $177.2 \mathrm{~g} / 500$ g-kernels respectively for actual oil yield; and $72.6 \%$ and $75.4 \%$ respectively for oil expelling efficiency of the screw press. 
Performance Evaluation Of Magnus Screw Press (Model Ms-100) For Palm Kernel Oil Extraction S. L. Ezeoha et al

Table 2: Results of batch 1 kernels conditioned to different KMCs(heated at $130^{\circ} \mathrm{C}$ for $10 \mathrm{~min}$ )and processed

\begin{tabular}{llllllll}
\hline $\begin{array}{l}\text { KMC } \\
(\%(w b))\end{array}$ & $\begin{array}{l}\text { Cake } \\
\text { output } \\
(\mathrm{g})^{*}\end{array}$ & $\begin{array}{l}\text { Grits } \\
\text { output } \\
(\mathrm{g})^{*}\end{array}$ & $\begin{array}{l}\text { Sludge } \\
\text { output } \\
(\mathrm{g})^{*}\end{array}$ & $\begin{array}{l}\text { Actual } \\
\text { Oil yield } \\
(\mathrm{g})^{*}\end{array}$ & $\begin{array}{l}\text { Total } \\
\text { Output } \\
(\mathrm{g})^{*}\end{array}$ & $\begin{array}{l}\text { Throughput } \\
\text { Capacity } \\
(\mathrm{kg} / \mathrm{h})\end{array}$ & $\begin{array}{l}\text { Oil extraction } \\
\text { efficiency } \\
(\%)\end{array}$ \\
\hline 3 & 206.9 & 66.0 & 19.7 & 138.7 & 431.3 & 88.0 & 60.0 \\
5 & 185.1 & 77.6 & 20.4 & 179.7 & 462.8 & 94.4 & 77.8 \\
7 & 177.5 & 76.7 & 17.8 & 168.7 & 440.6 & 89.9 & 73.0 \\
10 & 212.4 & 51.1 & 20.2 & 169.5 & 453.2 & 92.5 & 73.4 \\
Average & 195.5 & 67.9 & 19.5 & 164.2 & 447.0 & 91.2 & 71.1 \\
\hline
\end{tabular}

$g^{*}=g / 500$ g-kernels; Kernel oil content $(\mathrm{KOC})$ for batch 1 kernels $=46.2 \% \mathrm{~W} / \mathrm{w}$ basis; KMC $=$ kernel moisture content; the figures in the table are actually means of 2 replications each.

Table 3: Results of batch 2 kernels (at 3\% KMC w.b.) heated at different KHTs (for 10 min) and processed

\begin{tabular}{llllllll}
\hline $\begin{array}{l}\text { KHT } \\
\left({ }^{\circ} \mathrm{C}\right)\end{array}$ & $\begin{array}{l}\text { cake } \\
\text { output } \\
(\mathrm{g})^{*}\end{array}$ & $\begin{array}{l}\text { Grits } \\
\text { output } \\
(\mathrm{g}) *\end{array}$ & $\begin{array}{l}\text { Sludge } \\
\text { output }(\mathrm{g})^{*}\end{array}$ & $\begin{array}{l}\text { Actual oil } \\
\text { yield }(\mathrm{g})^{*}\end{array}$ & $\begin{array}{l}\text { Total } \\
\text { output } \\
(\mathrm{g})^{*}\end{array}$ & $\begin{array}{l}\text { Throughput } \\
\text { Capacity }(\mathrm{kg} / \mathrm{h})\end{array}$ & $\begin{array}{l}\text { Oil } \\
\text { efficiency }(\%)\end{array}$ \\
\hline 30 & 210.0 & 73.1 & 20.1 & 157.3 & 460.5 & 94.0 & 69.9 \\
50 & 188.2 & 73.9 & 19.8 & 160.9 & 442.8 & 91.8 & 71.5 \\
90 & 186.3 & 79.9 & 18.2 & 165.5 & 449.9 & 91.2 & 73.6 \\
130 & 185.0 & 77.3 & 15.1 & 169.4 & 446.8 & 91.2 & 75.3 \\
Average & 192.4 & 76.1 & 18.3 & 163.3 & 450.0 & 91.8 & 72.6 \\
\hline
\end{tabular}

$g^{*}=g / 500$ g-kernels; Kernel oil content (KOC) for batch $2=45 \% \mathrm{w} / \mathrm{w}$ basis, $\mathrm{KHT}=$ kernel heating temperature; the figures in the table are mean values for 2 replicates each.

Table 4: Results of batch 3 kernels (at 6.6\% KMC w.b.) heated at $80^{\circ} \mathrm{C}$ for different KHDs and processed

\begin{tabular}{llllllll}
\hline $\begin{array}{l}\text { KHD } \\
(\text { min })\end{array}$ & $\begin{array}{l}\text { Cake } \\
\text { output }(\mathrm{g})^{*}\end{array}$ & $\begin{array}{l}\text { Grits } \\
\text { output }(\mathrm{g})^{*}\end{array}$ & $\begin{array}{l}\text { Sludge } \\
\text { output }(\mathrm{g})^{*}\end{array}$ & $\begin{array}{l}\text { Actual oil } \\
\text { yield } \\
(\mathrm{g})^{*}\end{array}$ & $\begin{array}{l}\text { Total } \\
\text { output } \\
(\mathrm{g})^{*}\end{array}$ & $\begin{array}{l}\text { Throughput } \\
\text { Capacity } \\
(\mathrm{kg} / \mathrm{h})\end{array}$ & $\begin{array}{l}\text { Oil } \\
\text { Efficiency }(\mathrm{OEE})(\%)\end{array}$ \\
\hline 5 & 216.3 & 74.7 & 15.5 & 170.0 & 476.5 & 97.2 & 72.3 \\
10 & 157.2 & 73.3 & 18.0 & 188.0 & 436.5 & 89.1 & 80.0 \\
15 & 185.6 & 69.1 & 14.6 & 170.7 & 440.0 & 89.8 & 72.6 \\
20 & 190.5 & 61.6 & 19.1 & 180.0 & 451.2 & 92.1 & 76.6 \\
Average & 187.4 & 69.7 & 16.8 & 177.2 & 451.1 & 92.1 & 75.4
\end{tabular}

$g^{*}=g / 500$-kernels; Kernel oil content (KOC) for batch $3=47 \% \mathrm{w} / \mathrm{w}$ basis; $\mathrm{KHD}=$ kernel heating duration; the figures in the table are actually means of 2 replicates each.

Table 5 (extracted from Tables 2 to 4 ) shows a summary of actual oil yields and oil expelling efficiencies for batches 1 to 3 experiments. The tabulated results indicate that MS-100 screw press has an average actual oil yield of $168.2 \mathrm{~g} / 500 \mathrm{~g}$-kernels equivalent to an average oil expelling efficiency of $73.0 \%$. The press has an average cake output of $191.8 \mathrm{~g} / 500 \mathrm{~g}$ - kernels; an average un-pressed kernel grits formation of 71.2 $\mathrm{g} / 500 \mathrm{~g}$-kernels; and an average oil sludge formation of $18.2 \mathrm{~g} / 500$ g-kernels (Table 6).

The results of the press feed rates (FR), cake oil content (COC), and specific energy consumption (SEC) from the different experiments using B4 kernels are shown in Table 7. The results indicate values of $101.7 \mathrm{~kg} / \mathrm{h}, 13.6 \%$, and $0.44 \mathrm{kWh} / \mathrm{kg}$-kernels, for average FR, COC, and SEC, respectively. The range of temperatures of the PKO expressed by the screw press was $60-70^{\circ} \mathrm{C}$.
Table 5: Summary of actual oil yields (AOY) and oil expelling efficiencies (OEE)

\begin{tabular}{cccc}
\hline $\begin{array}{c}\text { Kernel } \\
\text { Batch No. }\end{array}$ & $\begin{array}{c}\text { AOY (g/500 g } \\
\text { kernels })\end{array}$ & $\begin{array}{c}\text { PAOY } \\
(\%)\end{array}$ & OEE (\%) \\
\hline 1 & 164.2 & 32.8 & 71.1 \\
2 & 163.3 & 32.7 & 72.6 \\
3 & 177.2 & 35.4 & 75.4 \\
Average & $168.2 \pm 7.8$ & $33.6 \pm 1.5$ & $73.0 \pm 2.2$ \\
\hline
\end{tabular}

Table 6: Summary of cake, un-pressed kernel grits, and oil sludge outputs

\begin{tabular}{llll}
\hline $\begin{array}{l}\text { Kernel } \\
\text { batch }\end{array}$ & $\begin{array}{l}\text { Cake output } \\
(\mathrm{g})^{*}\end{array}$ & $\begin{array}{l}\text { Grits output } \\
(\mathrm{g})^{*}\end{array}$ & $\begin{array}{l}\text { Sludge } \\
\text { output }(\mathrm{g})^{*}\end{array}$ \\
\hline 1 & 195.5 & 67.9 & 19.5 \\
2 & 192.4 & 76.1 & 18.3 \\
3 & 187.4 & 69.7 & 16.8 \\
Average & $191.8 \pm 4.1$ & $71.2 \pm 4.3$ & $18.2 \pm 1.4$ \\
\hline$(\mathrm{g})^{*}=\mathrm{g} / 500$ g-kernels & &
\end{tabular}




\subsection{Analysis of the OFAT Experiments on Effects of KMCs, KHTs, and KHDs on OEE}

Table 8 shows the raw data for the experiment on effect of KMCs on the OEE of Magnus Screw Press. It reveals that 4 levels of KMCs at 2 replications were used to realize the OEE percentages (see Table 2). The information in Table 8 was used to manually compute the sum of squares (SS) and degree of freedom (d.f.) values in Table 9.

Table 9 shows the ANOVA of the effect of KMCs on OEE of MS-100 screw press. This table (based on Table 8) shows that the F-calculated ( $\left.\mathrm{F}_{\text {-cal }}\right)$ is greater than F-tabulated (Ftab) at both $5 \%$ and $1 \%$ levels of significance (43.7> 6.59 and 16.69). We therefore conclude that the treatment means (averages) differ, that is, the KMC of processed kernel samples significantly affects the OEE of the screw press. Thus, the best KMC is $5 \%$ w.b. with the highest OEE of $77.8 \%$.

Table 10 shows the raw data for the experiment on effect of KHTs on the OEE of Magnus Screw Press. It reveals that 4 levels of KHTs at 2 replications were used to realize the OEE percentages (see Table 3). The information in Table 10 was used to manually compute the sum of squares (SS) and degree of freedom (d.f.) values in Table 11.

Table 11 shows the ANOVA of the effect of KHTs on OEE of MS-100 screw press. This table (based on Table 10) shows that the F-calculated (F-cal) is less than F-tabulated $\left(\mathrm{F}_{\text {-tab}}\right)$ at both $5 \%$ and $1 \%$ levels of significance $(3.7<$ 6.59 and 16.69). We therefore conclude that the treatment means (averages) are homogenous. This means that, though heating is required for high OEE, any of the heating temperatures $\left(50,90,130^{\circ} \mathrm{C}\right)$ could be employed to achieve the high OEE.

Table 12 shows the raw data for the experiment on effect of KHDs on the OEE of Magnus Screw Press. It reveals that 4 levels of KHDs at 2 replications were used to realize the OEE percentages (see Table 4). The information in Table 12 was used to manually compute the sum of squares (SS) and degree of freedom (d.f.) values in Table 13.

Table 7: Press feed rate (FR), SEC, and cake oil content (COC)

\begin{tabular}{cccccc}
\hline $\begin{array}{c}\text { Sample } \\
\text { No. }\end{array}$ & $\begin{array}{c}\text { Sample mass } \\
(\mathrm{kg})\end{array}$ & $\begin{array}{c}\text { Processing time } \\
\text { (minutes) }\end{array}$ & FR (kg/h) & COC $(\%)$ & SEC $(\mathrm{kWh} / \mathrm{kg})$ \\
\hline 1 & 5 & 3.1 & 96.77 & 13.1 & 0.47 \\
2 & 6 & 3.5 & 102.86 & 14.5 & 0.44 \\
3 & 10 & 6.0 & 100.00 & 13.8 & 0.45 \\
4 & 12 & 7.0 & 102.86 & 13.5 & 0.44 \\
5 & 15 & 8.3 & 105.88 & 12.9 & 0.42 \\
Average & & & $101.67 \pm 3.44$ & $13.6 \pm 0.63$ & $0.44 \mathrm{kWh} / \mathrm{kg} \pm 0.02$ \\
\hline
\end{tabular}

Table 8: Raw result of experiment on effect of KMCS on OEE of Magnus Screw Press

\begin{tabular}{c|c|c|c|c}
\hline \multicolumn{5}{c}{ Observed OEE (\%), KMC } \\
\hline (\% w.b) & 1 & 2 & Total & Average \\
\hline 3 & 58.9 & 61.1 & 120.0 & 60.0 \\
5 & 79.1 & 76.5 & 155.6 & 77.8 \\
7 & 74.0 & 72.0 & 146.0 & 73.0 \\
10 & 72.2 & 74.6 & 146.8 & 28.4 \\
\hline \multicolumn{7}{l}{ Total s } & 5684.0 & 2820 \\
\hline
\end{tabular}

Table 9: ANOVA for the effect of KMCS on OEE of Magnus Screw Press

\begin{tabular}{l|l|l|l|l|l|l}
\hline Sources of Variation & SS & d.f & MS & F-cal & F_tab 5\% & F $_{\text {W }}(1 \%)$ \\
\hline KMC & 354 & 3 & 118 & 43.7 & 6.59 & 16.69 \\
Error & 10.7 & 4 & 2.7 & & & \\
Total & 364.7 & 7 & & & & \\
\hline
\end{tabular}

Table 10: Raw result of experiment on effect of KHTS on OEE of Magnus Screw Press

\begin{tabular}{l|l|l|l|l}
\hline \multicolumn{7}{c}{.Observed OEE (\%), KHT } & Averages \\
\hline$\left({ }^{0} \mathrm{c}\right)$ & 1 & 2 & Totals & 69.9 \\
\hline 30 & 68.9 & 71.3 & 139.8 & 71.5 \\
50 & 70.6 & 72.4 & 143.0 & 73.6 \\
90 & 75.1 & 72.1 & 147.2 & 75.3 \\
130 & 74.3 & 76.3 & 150.6 & 290.3 \\
\hline \multicolumn{7}{l}{} \\
\hline
\end{tabular}


Table 11: ANOVA for the effect of KHTs on OEE of Magnus Screw Press

\begin{tabular}{c|c|c|c|c|c|c}
\hline Sources of Variation & SS & d.f & MS & F-cal & F-tab(5\%) & F_1 (1\%) \\
\hline KHT & 33.6 & 3 & 11.2 & 3.7 & 6.59 & 16.69 \\
Error & 12.0 & 4 & 3.0 & & & \\
Total & 45.6 & 7 & & & & \\
\hline
\end{tabular}

Table 12: Raw result of experiment on effect of KHDs on OEE of Magnus Screw Press

\begin{tabular}{l|l|l|l|l}
\hline \multicolumn{7}{c}{ Observed OEE (\%)...KHD } \\
\hline$(\min )$ & 1 & 2 & Totals & Averages \\
\hline 5 & 71.5 & 73.1 & 144.6 & 72.3 \\
10 & 81.2 & 78.8 & 160.0 & 80.0 \\
15 & 73.1 & 72.1 & 145.2 & 72.6 \\
20 & 75.5 & 77.7 & 153.2 & 76.6 \\
\hline \multicolumn{7}{l}{} \\
\hline \multicolumn{7}{l}{} \\
\hline
\end{tabular}

Table 13: ANOVA for the effect of KHDs on OEE of Magnus Screw Press

\begin{tabular}{l|l|l|l|l|l|l}
\hline Sources of Variation & SSS & d.f & MS & F-cal & F_tab (5\%) & F_1 (1\%) \\
\hline KHT & 80.1 & 3 & 26.7 & 14.8 & 6.59 & 16.69 \\
Error & 71 & 4 & 1.8 & & & \\
Total & 87.2 & 7 & & & & \\
\hline
\end{tabular}

Table 13 shows the ANOVA of the effect of KHDs on OEE of MS-100 screw press. This table (based on Table 12) shows that the F-calculated $\left(\mathrm{F}_{\text {-cal }}\right)$ is greater than $\mathrm{F}$ tabulated $\left(\mathrm{F}_{-\mathrm{tab}}\right)$ at $5 \%$ but lower at $1 \%$ levels of significance $(14.8>6.59$; but $14.8<16.69)$. We therefore conclude that the treatment means (averages) differ at $5 \%$ level of significance, that is, the KHD of processed kernel samples significantly affects the OEE of the screw press. Thus, the best KHD is $10 \mathrm{~min}$ with the highest OEE of $80.0 \%$. At $1 \%$ level of significance, however, the different level means are homogenous, that is, any of the durations could be used to achieve high OEE. In that circumstance, however, it is more economical to heat the kernels for 5 or10 min than for 15 or $20 \mathrm{~min}$ to achieve the same target.

\subsection{Discussion of Results:}

The average oil expelling efficiency (73\%) of MS-100 screw press compares favourably with the press used by Akinoso [15]. Akinoso [15] used Fradex (Nigeria) manufactured palm kernel oil expeller model 500-G which was reported to have exhibited a maximum efficiency of $94.5 \%$. The average efficiency was however not reported. Therefore, the present press is deemed suitable for palm kernel oil extraction. The formation of un-pressed kernel grits by the press is the identified problem of the screw press. Ideally, all crushed kernels (grits) should be pressed to extract PKO and form cakes.

\section{CONCLUSIONS AND RECOMMENDATIONS}

\subsection{Conclusions}

Based on the results of this investigation the following conclusions are made:
1. The MS-100 Screw Press has an average kernel processing capacity of $101.7 \pm 3.4 \mathrm{~kg} / \mathrm{h}$.

2. The average oil-content of the cakes produced by the screw press is approximately $14 \%$ (by weight).

3. The average specific energy consumption of the press is $0.44 \mathrm{kWh} / \mathrm{kg}$ of kernels.

4. The average oil extraction efficiency of the screw press is $73 \%$.

5. The optimum conditions of palm kernels for the achievement of high OEE are 5\% KMC (w.b.), 50 $130^{\circ} \mathrm{C}$ KHT, and 5 -10 min KHD.

6. The average kernel grits formation was71.2 g/500 g kernels equivalent to percentage not-pressed-grits formation of $14 \%(\mathrm{w} / \mathrm{w})$. This is a major problem because it reduces the oil expression efficiency of the screw press.

7. The average oil sludge formation was $18.2 \mathrm{~g} / 500 \mathrm{~g}$ kernels equivalent to percentage sludge formation of $3.6 \%(\mathrm{w} / \mathrm{w})$.

8. The percentage cake formation of the screw press was $36 \%$ (178.8 g/500 g kernels).

9. The Magnus (Nig.) model MS-100 screw press is suitable for palm kernel oil extraction based on its high oil extraction efficiency.

\subsection{Recommendations}

Based on the findings of this performance evaluation work the following recommendation is made:

The 14.2\% un-pressed kernel grits formation for the press is a functional problem. It, therefore, needs to be reduced or eliminated through design modifications so as to increase the oil expelling efficiency of the screw press. 


\section{REFERENCES}

[1] Adaba, C. S., Agunwamba, J. C., Nwoji, C. U., Onya, O. E. and Ozeh, S. "Comparative Cost and Strength Analysis of Cement and Aggregate Replacement Materials", Nigerian Journal of Technology, Vol. 31, Number 2, , pp 111-115. 2012.

[2] Ezeike. G. O. I. "Determination of Calorific Values of some Nigerian Bio-mass Solid Materials", Nigerian Journal of Technology, Vol. 7, Number 1, pp 21-33. 1983.

[3] Okoroigwe, E. C. and Saffron, C. M. "Determination of Bio-energy Potential of Palm Kernel Shell by Physicochemical Characterization", Nigerian Journal of Technology, Vol. 31, Number 3, pp 329-335. 2012.

[4] Otunyo, A. W. "Palm Kernel Husk Ash (PKHA) as an Admixture (Accelerator) in Concrete", Nigerian Journal of Technology, Vol. 30, Number 3,, pp 60-66. 2011.

[5] Okpaluba, T. O. Design of Continuous Screw Press for Palm Kernel Oil Extraction. B.Eng. Project Report. Agricultural \& Bioresources Engineering Department, University of Nigeria, Nsukka. 1988.

[6] Obetta, S. E. Development of a Hot-water Palm Kernel Oil Extraction System. Ph.D Thesis, Department of Agricultural and Bioresources Engineering, University of Nigeria, Nsukka. 2003.

[7] Aiwize, E. A. and Achebo, J. I. "Liquid Soap Production with Blends of Rubber Seed Oil (RSO) and Palm Kernel Oil (PKO) with Locally Sourced Caustic Potash (KOH)", Nigerian Journal of Technology, Vol. 31, Number 1, , pp 63-67. 2012.
[8] Olawepo - Olayiwole, O. S. and L. Balogun. Performance evaluation of a palm kernel oil extracting machine. Proceedings of NIAE, vol. 26, p. 308-311. 2004.

[9] Olayanju, T. M. A., R. Akinoso, and O. M. Oyeku. An investigation into the machine parameters of some vegetable oil expellers. Proceedings of NIAE. Vol. 26. p. 387-390. 2004

[10] Alonge, A.F., M. A. Olaniyan, K. Oje, and C. O. Agbaje. Development of a screw press for village level groundnut oil extraction. Journal of Agricultural Engineering and Technology, vol.12, p. 46-53. 2004.

[11] Olayanju, T. M. A. Design, Development and Evaluation of Beniseed Oil Expeller. JAET, Vol.12, p. 70-78. 2004.

[12] Burkhardt, G. J. Effect of Pitch, Radial clearance, Hopper exposure and Head on Performance of Screw feeders. Transactions of the American Society of Agricultural Engineers, p.685-690. 1967.

[13] Ojomo, A. O., Ologunagba, F. O., Alagha, S. A. Evaluation of a Locally Fabricated Oil Screw Expelling Machine. Global Journal of Researches in Engineering, Vol. 11 (7) 2011.

[14] Magnus (Nig.) Materials Fabrications, No. 6 Mbuke Street, Nsukka, Enugu State, Nigeria.

[15] Akinoso, R., Igbeka, J. C., Olayanju, T. M. A. and L. K. Bankole. Modeling of oil expression from palm Kernel. Agricultural Engineering International: the CIGR E-journal. Vol. V III. October, 2006.

[16] Ezeoha, S. L. Effects of process variables on the extraction of palm kernel oil using a screw press (Unpublished Doctoral Thesis), Department of Agricultural and Bioresources Engineering, University of Nigeria, Nsukka. 2016. 